\title{
Business Strategy Role as Mediation of Management Capability on Business Performance Seaweed In South Sulawesi
}

\section{Suryawati Salam* and Andi Gusti}

Bosowa University of Makassar, Indonesia

\begin{abstract}
This study aims to examine and analyze: whether the business strategy is directly influenced by management ability, entrepreneurship orientation, both directly and indirectly, through businness strategy as mediation. Theoretically, the results of this research is expected to be complete the repertoire of knowledge in strategic management field, especially micro and small entrepreneurship, so it can be useful for academics, practitioners and government. The population in this study is businesman. Respondents used as sample are 74 people seaweed entrepreneurs at micro and small scalemethod is census and an analytical method used in hypothesis testing is Path Analysis. The results of this study indicate that: (1) management capability indirectly affects on businessstrategy, (2) entrepreneurship orientation directly influences business strategy. (3) entrepreneurship orientation indirectly affect on business performance business through business strategy.
\end{abstract}

Keywords: Management; Entrepreneurship; Business strategy; Seaweed

\section{Introduction}

A seaweed may belong to one of several groups of multicellular algae: the red algae, green algae, and brown algae. As these three groups do not have a common multicellular ancestor, the seaweed are in a polyphyletic group. In addition, some tuft-forming bluegreen algae (Cyanobacteria) are sometimes considered to be seaweed "seaweed" is a colloquial term and lacks a formal definition.

Two specific environmental requirements dominate seaweed ecology. These are the presence of seawater (or at least brackish water) and the presence of light sufficient to drive photosynthesis. Another common requirement is a firm attachment point, although some genera such as Sargassum and Gracilaria have species that float freely. As a result, seaweed most commonly inhabit the part of a sea that is close to the shore (the littoral zone) and within that zone more frequently on rocky shores than on sand or shingle. Seaweed occupy a wide range of ecological niches. The highest elevation is only wetted by the tops of sea spray, the lowest is several meters deep. In some areas, littoral seaweed can extend several miles out to sea. The limiting factor in such cases is sunlight availability. The deepest living seaweed are some species of red algae [1].

Others have adapted to live in tidal rock pools. In this habitat seaweed must withstand rapidly changing temperature and salinity and even occasional drying.

Saweed marketing in the is inseparable with the South Sulawesi province, here the South Sulawesi seaweed comoditie are marketed for export purpose, inter-provincial and local. While micro and small seaweed entrepreneurs in still market their products on the local markets which are on a large scale and industrial companies in the city of Makasar. While for Makassar city almost entirely is marketed among the provinces like to Jakarta, and Surabaya in the dried seaweed shape. Accordingly, since he seaweed is mostly done by micro and small enterprises, so that Juoro [2] explains that small and micro business can be considered as the basis for the business of the industry structure, this is because the items products manufactured by big business is being sub working at SME, in addition to the selling price off SME products are relatively cheap [3].
The task of a manager is fairly complex and multidimensional; it requires a number of skills. Skills required to manage a department or an organization an be sumrized in three categories: conceptual, human and technical [4]. While Alesandri [5] proves that the risk influence goes beyond the decision proccess, thus rationalizing the decisionmaking process affects the output decision [6]. In line with Ramo [7], it is proved that the motional and social skills impact on productivity.

Therefore, management skills significantly affects on the isk and product development [8]. In the same way, the organizational innovation and organizational learning together promote entrepreneurship to improve the competitiveness [9]. Positive management capabilities have significant impact on the performance of small and medium enterprises. The finding also show that, if an entrepreneur has good management skill, it will improve their business performance. Along with Latif [10], he proves that if an entrepreneur has good management skills, it will improve their business performance.

Amit and Schumaker [11] prove that the management capabilities significantly influence business performance. Furthermore, Daft [4] proves that management ability has no affect on the development of technology, in addition globalization and inovation that is the part of the business strategy in order to improve business performance. Some characteristics of the entrepreneur described by Idrus [12], greatly affect he success of the business performance running. These characteristics are self confidence, task result oriented, risk taker in the form of time money, health, and spirit, havin leadership attitude, having authenticity (originality), being future oriented future oriented). The success of the business is determined how many feature are embed in the entrepreneur's soul.

*Corresponding author: Suryawati Salam, Bosowa University of Makassar Indonesia, Tel: 62411452901; E-mail: suryawatisalam@yahoo.com

Received November 23, 2016; Accepted December 15, 2016; Published December 22, 2016

Citation: Salam S, Gusti A (2016) Business Strategy Role as Mediation of Management Capability on Business Performance Seaweed In South Sulawesi. Bus Eco J 7: 272. doi: 10.4172/2151-6219.1000272

Copyright: $\odot 2016$ Salam S, et al. This is an open-access article distributed unde the terms of the Creative Commons Attribution License, which permits unrestricted use, distribution, and reproduction in any medium, provided the original author and source are credited. 
There are some researches on entrepreneurial orientation such as Zahra et al. [13] proves that a positive relationship between entrepreneurial orientation, profitability and growth.

Similar with Zahra and Covin [13], they prove that the existence of a positive relationship and significant influence. Suci has also proved that entrepreneurial orientation has positive and significant impac on business strategy and business performance in mall and medium enterprises. Therefore to determine whether there is inluence of entrepreneurship orientation to business strategy and business performance, Lee and Tsang [14].

Many experts emphasize the role of entrepreneurship in small and medium enterprises. For small and medium enterprises, there are a lot of hings studied related to business strategy, strategic entrepreneurship and innovation [15]. While the ME business strategy, regarding to the suitability of internal capabilities and activities of the company with the external environment in which companies must compete using strategic decisions and usually use the following strategies: new products on the previous market, the product in a particular market niche, being into specific segments and making changes on product characteristics [3].

Generally, small and medium entrepreneurs rely on many strategies that are based on the spirit of entrepreneurship [16]. Meanwhile, according to Suwarsono [17], he explains that the intensities and formality strategies on SME are quite simple and partial. Through the steps, a company tries to achieve strategic competitiveness and profits above the average; therefore there are two main models to be achieved [15].

\section{Methods}

The approach used in this study is a quantitative approach. This study also adds some explanatory information from some respondents to complete the results obtained from the quantitative approach. This research is a census research, where the entire population is selected for the study. The population is small nd micro entrepreneur amounted at 74 respondents in details: 16 people of micro and 58 people of small entrepreneurs which are included as criteria in Law Noo.20 in 2008.

In the design of the questionaire set, it uses some indicators that reflect latent variables and items and also open-ended questions with a Likert scale, the validity and reliability tests are also performed. To test the proposed model, the statistical techniques used is Path Analysis [18].

\section{Results}

\section{Hypothesis testing}

By using path nalysis with confirmatory factor analysis (CFA) program AMO 18.0 (Analysis of Moment Structure, Arbukle [19]).

\section{Criteria evaluation for goodness}

Evaluation of the accuracy of the model has essentially one at the time the model is estimated by AMO. A complete evaluation of thiis model can be done as follows.

\section{Evaluation of the normality asumption fulfilled up data}

Univariate and multivariate normality of the data are used in this analysis; tested by using AMOS 18 about he assessment of normality. By referring to the value in column CR it can be concluded that all the variables use normal distribution.

\section{Evaluation of multicolinearity and singularity}

By using Amos 18 software the evaluation of Multicolinearity and
Singularity can be detected by looking at the determinant value of the sample covariance matrix. It indicates that the determinant value of the sample covariance matrix is 0.003 . It is concluded that there is no multicollinearity or singularity, thus the data is fit to use.

\section{Discussion}

The management ability owned by entrepreneurs does not support the business strategy. Or the management ability influence indirectly on the business strategy. These findings contradict the results of previoous studies, according Alesandri [5], Nooraie [6], Ramo [7], Garcia [9] Surachman [8] prove that the management skill influences significantly on product risk and development.

The entrepreneurship orientation owned by entrepreneurs supports the business strategy. Or the entrepreneurship orientation directly influences the development of the business strategy. This finding is consistent with results of previous studies, conducted by McCarthy [20], Idrus [12], Zahra and Covin [13], Suci whichh prove that entrepreneurship orientation has positive and significant impact on business strategy and business performance of small and medium enterprises.

The management ability owned entrepreneurs improves their business performance. Or the management abilitty directly afects the business performance. These findings are consistent with previous studies by Robbins and Coulter, Suci that prove if the management ability has positive and significant impact on business performance.

The entrepreneurship orientation can improve the business performance, when implementing the appropriate business strategy. The intepreneurship orientation indirectly affects on business performance but through the business strategy. These findings contradict the results of the studies by McCarthy [20], Covin and Selvin [21], Idrus [12], Steward et al. and Vitale et al. [22], Smart and Conant [23], proving that entrepreneurship orientatiion has positive and significant impact on business strategy and business performance of small and medium enterprises.

The business strategy can improve the business performance. Or business strategy directly affects the performmance of he business. This finding is consistent with results of previous studies, as the study conducted by Mokko [24], Philips, Covin and Slavin [21], Miller and Friesen [25] proving that operating performance improves if yo have competitive advantages.

\section{Conclusions}

1. The management ability possessed by an seaweed entrepreneur does not support the business strategy or the management ability indirectly afectts the business strategy.

2. The entrepreneurship orientation owned by an seaweed entrepreneur is proved supporting the business strategy. The entrepreneurship orientation directly influences the development of business strategy.

3. The management capabilities possessed by an seaweed entrepreneur is proven to improve the business performance. or the managemen ability directly effect the business performance.

\section{References}

1. Lewis JR (1964) The Ecology of Rocky Shores. The English Universities Press Ltd. 
Citation: Salam S, Gusti A (2016) Business Strategy Role as Mediation of Management Capability on Business Performance Seaweed In South Sulawesi. Bus Eco J 7: 272. doi: 10.4172/2151-6219.1000272

Page 3 of 3

2. Juoro U (1995) Global Competition and Economic Indonesia Decade 1990. An 8-year Prisma XIX.

3. Suryana (2003) Entrepreneurship Practical Guide Tips and Process to Success Salemba Four, Revised Edittion.

4. Daft RL (2002) Organization Theory and Design. (5thedn) West Publishing Company, St.Paul, MN

5. Alessanndri TM (2008) Risk and Procedural rationality, A Behavioral Theory Perspective, Journal of Strategy and management 1: 196-217.

6. Mahmod N (2008) Decision Magnituude of Impact and Straategic Deciision Markiing Process Output. Journal Management Decisioon 46: 6440-6655.

7. Ramo LG, Saris WE, Boyatzis RE (2009) The impact Of Soocial And Emotional Competencies On Effectiveness of Spanish Executives. Jouurnal of Management Development 28: 771-793.

8. Surachman (2007) Influence Skill Managemen And Business Orientation Against Acceptance Rate Risk and its Impact on Small Industries Product Development in Java Tinmurr. Journal of Management Applicaation.

9. Garcia VJ, Llorens-Montes FJ, Verdu-Jover AJ (2006) Antecedent and Consiquences of organizational innovation and Organizational Learning in Enterpreneurshif, Journal management \& Data Systems 106: 21-42.

10. Latif DA (2002) Moodel For Teaching The Management Skills Component O Managerial Effectiveness To Pharmacy Student. Review 66: 377-380.

11. Amit R, Schoeemaker PJH (1993) Strategic Assets and Organizational Rent Strategic Manageement Journal 14: 33-46.

12. Idrus MS (1999) Entrepreneurship Development Strategy (Entrepreneurship) and The Role of Higher Education in the Context oof Building a Competitive Advaantage (Advantagecompatitive) Bangsa Indonesia In Melinium Third Inauguration Speech Title Professor in Management Sciences UB Malang.

13. Zahra SA, Ireland RD Gutierrez I, Hitt MA (2000) Privatization and Entrepreneurial Transformation. merging Issues and A Future Research Agenda. Academ of Management Review 25: 509-524.
14. Lee DY, Tsanng EWK (2001) The Effect of Entrepreneurial Persoonality, Background and Neetwork Activities on Venture Growth. Journal of Management Studiees 38: 583-602.

15. Hitt M, Ireland D, Robert EH (2001) Strattegic Manaagement: Compettitive And Globalization. Fourth Edition Soutth-Western Publishing, USA

16. Hankinson A, Barttlett D, Duchheneaut B (2000) The key Factors In TheSmal Profiles Of Small- Medium Enterprise owner-Managers That Influence Business Performance. International Journal of Entrepreneurial Behavio and Research 3: $168-175$.

17. Suwarsono M (2008) Strategic Managgement. (4thedn) Publisher Schoo ofEconomics YKPN Jogyakarta.

18. Solimun (2011) Structural Equation Modeling SEM) Lisre Dan Amoos, First published, Malang State Univversity of Malang.

19. Arbuckle JL, Wothke W (1999) Amos 8.0 Users Guide: SPSS, Small Waters Corporation.

20. McCartthy B (2003) The mpact of Thhe Entrepreneur Personality on The Strategy Format and Plaanning Process In SME's. Journal of Managgement 1544-1572.

21. Covin JG, Slevin DP (1991) Strategic Management of Small Firms in Hosttile AndBegin Environment. Strategic Management Journal 10: 75-87.

22. Vitale R, Giglieraano J, Miles M (2003) Entrepreneurial Orientation, Market Orientation, and Performance In Established and Start-Up Firms.

23. Smart DT, Conant JS (1994) Entrepreneurial Orientation, Disstinctive MarketingCompetencies And Organisational Performance. Journal of Applied Business Reesearch 10: 228-238.

24. Moko W (2008) Implementation of Strategies to improve the Competitiveness of SMEs Merchants Food and Drink In Malang. Jouurnal of Management Applicatioon 6: 131-138.

25. Miller D, Friesen $P$ (1988) Archetytypes of Strategy Formulation. Management Science 24: 921-933. 